\title{
Özdeşleşmenin Reklama Karşı Tutum ve Satın Alma Niyeti Üzerindeki Etkisinde Ünlü-Ürün Uyumunun Ilımlaştırıcı Rolü ${ }^{1}$
}

\author{
Semra Doğan² \\ B. Zafer Erdoğan ${ }^{3}$
}

Özdeşleşmenin Reklama Karşı Tutum ve Satın Alma Niyeti Üzerindeki Etkisinde Ünlü-Ürün Uyumunun Ilımlaştırıcı Rolü

\section{Öz}

Bu çalışmada bireyin ünlü ile özdeşleşmesinin reklama karşı tutum ve satın alma niyetine etkisinde reklamdaki ünlü ve ürün arasında algılanan uyumun ılımlaştırıcı etkisi sınanmıştır. Bu kapsamda Facebook üzerinden 18 yaş üzeri 513 katılımcıdan toplanan örneklem üzerinde bahsedilen yapıların yer aldığı model test edilmiştir. Model testine yönelik analizler SPSS ve AMOS paket programlarıyla yapılmış ve özdeşleşmenin ünlüye özenme temelinde sadece reklama karşı tutum üzerinde etkisi olduğu görülürken inanç, tutum, değer ve diğer benzerlik kriterlerine bağı benzerlik algısının konu yapılar üzerinde herhangi bir etkisi olmadığı ortaya konmuştur. Ünlü-ürün uyum düzeyinin ise yüksek uyumda etki katsayılarının çoğunluğunu anlamlı bir şekilde arttırdığı; satın alma niyetinde ise temel belirleyicinin markaya yönelik tutum olduğu görülmüştür.

Anahtar Kelimeler: Reklamlarda Ünlü Kullanımı, ÜnlüÜrün Uyumu, Özenerek Özdeşleşme, Benzerliğe Bağlı Özdeşleşme, Ilımlaştırıcı Etki
The Moderating Role of Celebrity-Product Match-up on the Effect of Identification on Attitude Towards Advertising and Purchase Intention

Abstract

In this study, the moderator role of perceived match-up between the celebrity and the product on the effect of identification on the attitude towads ad and purchase intention was examined. The research model was tested on the sample collected from 513 participants over the age of 18 on Facebook. Analyzes carried out using SPSS and AMOS indicated that wishful identification has an effect on attitudes towards advertising, while the perception of similarity based on belief, attitude, value like criteria has no effect on the any of the variables. It has also been revealed that the most of the coefficients significantly increased in the high celebrity-product match-up condition. Attitude towards the brand is also the main indicator in the purchase intent.

Keywords: Celebrity Endorsement, Celebrity-Product Match-Up, Wishful Identification, Similarity Identification, Moderating Role

\section{Giriş}

Bireyler tüketim eylemlerini salt ürünlerin faydalarını gözeterek gerçekleştirmezler, aynı zamanda ürünlerin taşıdıkları sembolik anlamları da gözetirler ve gönüllü yapılan tüm tüketim davranışları bilinçli ya da değil, sembolik anlamlar taşır. Buna bağlı olarak da tüketim tercihlerinde seçeneklerin taşıdığı sembolik anlamlar tüketicinin tercih sebebinde belirleyici olacaktır (Levy, 1959; Hirschman, 1981). İlgili literatür, sahip olunan nesnelerin, tüketicilerin genişletilmiş benliklerinin önemli bir parçası olarak görüldüklerinden tüketicilerin de bu sahiplikleri ile ifade edildiklerini ifade etmektedir (Belk, 1988). Tüketim bireyin kişisel ve sosyal dünyasının yaratılması ve sürdürülmesi için anlam ve değerlerin temininde önemli bir role sahip olduğundan reklam da bu sembolik anlamların temel kaynaklarından biri olarak görülmektedir. Bu

\footnotetext{
${ }^{1}$ Bu çalışma, Anadolu Üniversitesi BAP Komisyonu tarafından $1701 E 024$ proje kodu ile desteklenen "Doğan, Semra (2018). Özdeşleşmenin Reklama Karşı Tutum ve Satın Alma Niyeti Üzerindeki Etkisinde Ünlü-Ürün Uyumunun Ilımlaştırıcı Rolü" künyeli doktora tezinden geliştirilmiş olup 23.Pazarlama Kongresi'nde özet olarak sunulan bildirinin geliştirilmiş ve genişletilmiş versiyonudur.

2 Dr. Öğr. Üyesi, Kütahya Dumlupınar Üniversitesi, IïBF İşletme Bölümü, semra.dogan@dpu.edu.tr, Yazar ORCID Bilgisi: https://orcid.org/0000-0002-6466-8734

3 Prof. Dr., Eskişehir Anadolu Üniversitesi, İşletme Fakültesi, bzerdogan@anadolu.edu.tr, Yazar ORCID Bilgisi: https://orcid.org/0000-0002-2147-7356
} 
kültürel anlamlar markalara transfer edilirken markalar da kimliğin oluşturulması ve sürdürülmesinde sembolik kaynak olarak kullanılmaktadır (McCrackern, 1989). Tüketim sembollerini ise sosyalleşme süreciyle ve reklam gibi kitle medyalarına maruz kalarak öğrenen ve geliştiren tüketiciler nezdinde ise aynı ürün her birey için aynı sembolik anlamı taşımaz. Bir ürün çok çeşitli anlamlar taşıyabilir çünkü anlamın yaratılmasında belirleyici olmadığı gibi tek yönlü de değildir. Her birey bir ürüne birbirinden farklı ve bazen de uyumsuz kültürel anlamlar atfedebilir. Sosyalleşme süreciyle tüketiciler sadece bazı sembollerin ortak anlamlarını değil kendi sembolik anlam yorumlarını da geliştirmiş olurlar. Bireyin benlik oluşumunda yararlanabileceği sembolik kaynaklar ise yaşanan/doğrudan ya da dolaylı deneyimler şeklinde sınıflandırılabilir. Doğrudan deneyim gündelik hayat pratiklerini ve yüz yüze karşılaşmalarla edinilen deneyimleri kapsar. Bunlar gerçeklik olarak kanıksadığımız şeyler olduğundan yerleşiktir, anlıktır. Dolaylı deneyimler ise kitle iletişim kültürünün ve medya ürünlerinin tüketimini kapsar ve gündelik hayat pratiklerinden mekânsal olarak da geçici olması açısından da farklılık gösterir (Grubb ve Grathwohl, 1967).

Reklamlarda ünlü kullanımı da sıklıkla uygulanan reklam stratejilerinden biridir. Friedman ve Friedman (1979) ünlüyü (celebrity), reklama konu ürün sınıfından ziyade, özellikle eğlence endüstrisi ya da sporculardan seçilen kendi/farklı alandaki başarılarıyla topluma mal olmuş kişi (aktör, sporcu, eğlence adamı vs.) olarak tanımlamıştır. Ancak Keel ve Nataraajan'ın (2012) ifade ettikleri gibi günümüzde TV gösterileri, Youtube ve blogların artan popülaritesi "ünlü" tanımının da genişletilmesi gereğini doğurmuştur. Tüketiciler günümüz dijital dünyasında yeni otorite arayışlarına girmiş, kültürel dönüşümün de etkisiyle "ünlü" tanımını herkesçe tanınır, bilinir olmaktan biraz daha öteye götürmüşlerdir. Dolayısıyla reklamlarda ünlü kullanımı bağlamında ünlüyü, McCracken'ın (1989) toplum tarafından bilinirliği olan ve bu bilinirliği bir ürün/markanın reklamında yer almak suretiyle o ürün/marka adına kullanan kişi olarak tanımlamak daha kapsayıcı olacaktır. Reklamlarda ünlü kullanımı ile de ünlü, bir ürünü tavsiye etme, bir ürüne ismini verme, reklam yüzü olma ya da marka elçisi olmak suretiyle bir şekilde konu ürünün, dolayısıyla da anlamın bir parçası olur. Ünlünün anlam taşıcıyısı bu rolü, reklamda tercih edilen çekicilik unsurunun da belirleyicisidir.

Reklamlarda ünlü kullanımının davranış değişikliği yönündeki etkisinde geleneksel yaklaşım ise ünlünün karakteristiklerinin iknadaki etkisine odaklanmaktadır. Ünlünün reklama dikkat çekme, ürün grubuyla uyumlu olması halinde ikna etkisini arttırma, bireyin sosyal kabul kaygısını elimine etmedeki katkısı, genellikle beğenilen profil olmaları itibariyle reklamın ikna gücünü arttırdıkları çeşitli çalışmalarda ortaya konmuştur (Baker ve Churchill,1977; Kahle ve Homer, 1985; Kamins, 1990; Ratneshwar ve Chaiken, 1991). Bu çalışmada, geleneksel yaklaşımların ötesinde bireyin tüketim davranışını bir anlamda da benlik kavramlarını ve kimliklerini oluşturmak için gösterdikleri düşüncesinden yola çıkılmıştır (Belk, 1988; McCracken, 1989).

Büyük çoğunluğu ünlünün çekiciliği üzerine olmakla birlikte reklamlarda ünlü kullanımına ilişkin alanda birçok çalışma yapılmıştır (Baker ve Churchill, 1977; Kahle ve Homer, 1985; Erdogan, 1999; Simmers vd., 2009; Eisend ve Langner, 2010; Liu ve Brock, 2011). Öte yandan kaynağın güvenilir algılandığı ölçüde ikna gücünün artacağından yola çıkarak kaynak güvenilirliği temelli çalışmalar da alanda sıkça yer bulmuştur (Ohanian, 1990; 1991; Jin ve Phua, 2014). Ünlü ve ürün uyumu da reklamlarda ünlü kullanımında sıkça çalışılan bir diğer konudur (Baker ve Churchill, 1977; Kahle ve Homer, 1985; Kamins, 1990; Till ve Busler, 2000; Batra ve Homer, 2004; Roy vd., 2012; Wright, 2016). Ünlü-ürün uyumu hipotezi olarak kavramsallaştırılan yaklaşım, mesaj kaynağı olarak ünlünün imajı ve reklama konu ürünün imajı arasındaki algılanan 
uyum arttıkça ünlü ve reklamın ikna gücünün de artacağını ifade eder (Kamins, 1990; Erdogan, 1999).

Kelman'ın Sosyal Etki Teorisi (1961) olarak ortaya koyduğu üç süreç itaat, özdeşleşme ve içselleştirme süreçleri olup, özdeşleşme ve içselleştirme reklamlarda ünlü kullanımında çalışılan iki süreçtir. Kapitan ve Silvera'nın da (2016) ifade ettiği, alanda çok az çalışılan konulardan biri olarak bu çalışmada ünlü ile özdeşleşme konusuna yer verilmiş ve farklı cinsiyetler-kadın ve erkek- itibariyle ünlü ile kurulan özdeşleşme bağının gücü sınanmıştır. Alanda ünlüyle özdeşleşmeye ilişkin yapılan çalışmalar sınırlı olup bu kavramı reklam etkinliğine olan etkisi bakımından ele almaktadır (Brown ve Basil, 1995; Basil, 1996; Fraser ve Brown, 2002; Jin ve Phua, 2014). Çalışmayı önemli kılan bir diğer husus ise çalışmaya konu örneklem çerçevesidir. Nitekim medya karakterlerine özenme davranışına yönelik çalışmalar sıklıkla çocukların özenme davranışı üzerine tasarlanmaktadır (Bandura, 1977; Hoffner, 1996). Öte yandan izleyici kitlesine sunulan medya içeriğinin yetişkinlerin de özenebileceği modeller sunulduğunu söylemek mümkündür. Bu araştırma ile örneklem çerçevesi çocukların ötesine taşınmış ve 18 yaş ve üzerinde reklam içeriğine çeşitli kitle iletişim araçlarıyla (Televizyon ya da çevrimiçi içerik) maruz kalabilecek bireyler olarak belirlenmiştir. Ünlü-ürün uyumuna ilişkin çok sayıda çalışma yer almakla birlikte çok büyük bir çoğunluğu hipotetik reklam tasarımları üzerine kurgulanmıştır. Bu çalışma, gerçek ünlüler ve onların yer aldığı gerçek reklamlar-markalar ile tasarlanması açısından önem taşımakla birlikte reklamlarda ünlü kullanımına tüketici-ünlü uyumu bağlamında yorumlanan özdeşleşmeyi de dahil etmiştir. Çalışmanın bir diğer özgün katkısı da uyumun hem tüketici-ünlü hem de ürün-ünlü olarak eşanlı incelenmesi ve bunların etkileşiminin reklam etkinliğinde yorumlanması olarak görülmektedir. Taranan literatür itibariyle konuyu bu bağlam ve bu tasarımda inceleyen bir çalışmaya rastlanmamıştır.

Bu çalışmada seçilen bir sporcu erkek ve bir şarkıcı kadın ünlü ve yer aldıkları/almakta oldukları reklamlar taranmıştır. Sonrasında yürütülen ön araştırma ile ünlüler ve reklamında yer aldıkları markalarla uyum düzeyi ortaya konmuştur. Akabinde gerçekleştirilen pilot çalışma ile uyum düzeyine ilişkin bu derecelendirme kontrol edilmiş ve aynı zamanda veri toplama aracındaki ölçek ifadelerinin anlaşılırlığı da ikinci aşama ön araştırma ile sınanmıştır. Son olarak yürütülen ana araştırma ile model testi gerçekleştirilmiştir.

\section{Kuramsal Çerçeve}

Reklamlarda ünlü kullanımına ilişkin araştırmaların önemli bir kısmı ünlü kullanımının işlevselliği ve ünlü seçiminin en iyi nasıl yapılacağına ilişkindir (Erdoğan,1999). İlgili literatür kaynak konumundaki ünlülerin karakteristiklerine ilişkin, güvenilirlik, uzmanlık, çekicilik, güç ve ünlünün bahse konu karakteristikleri itibariyle reklama konu ürünle uyumuna yönelik faktörlere vurgu yapmaktadır.

\subsection{Reklamlarda Ünlü Kullanımının Dayandığı Teoriler}

Reklamlarda ünlü kullanımı Sosyal Adaptasyon Teorisi (Social Adaptation Theory); Denge Teorisi (Balance Theory); Atfetme Teorisi (Attribution Theory); Çağrışımsal Öğrenme Teorisi; Iknanın Detaylandırma Olasılığı (Elaboration Likelihood of Persuasion) ve Sosyal Etki Teorisi (Social Influence Theory) gibi teorilerle ilişkilendirilebilmektedir (Kahle ve Homer, 1985; Heider, 1958; Kelley, 1973; Petty vd., 1983; Kelman, 1961). Bu çalışmada Sosyal Etki Teorisi unsurlarından biri olan Özdeşleşme boyutu ele alınacağından Sosyal Etki Teorisi ve Özdeşleşme kavramı detayıyla aşağıda incelenmiştir. 


\subsubsection{Kelman'ın Sosyal Etki Teorisi}

Sosyal etki, bireyin başka bir kişi ya da grupla etkileşime girmesi sonucunda düşünce, duygu, tutum ya da davranışlarında meydana gelen değişim olarak ifade edilmektedir (Rashotte, 2007). Herbert Kelman (1961) sosyal etkinin kişinin bir başka kişi ya da grubun etkisini kabul etmesine dayalı içselleştirme, özdeşleşme ve itaat olmak üzere üç aşaması olduğunu ifade etmiştir. Kaynak özellikleri açısından ise bu üç sürecin karşılı̆̆ı kaynak güvenilirliği, kaynak çekiciliği ve kaynak gücüdür (Biswas vd., 2009). Bir anlamda mesajın alıcısının kaynağı güvenilir bulduğu ölçüde mesajı içselleştireceğini, çekici bulduğu ölçüde kendisini kaynakla özdeşleştireceğini ve güçlü bulduğu ölçüde de ona itaat edeceğini söylemek mümkündür. Bu da sırasıyla kaynağın uzmanlık ve inanıır bulunduğu ölçüde güvenilir bulunacağını (Hovland ve Weiss, 1951), aşina, sevilir ve benzer bulunduğu ölçüde çekici bulunacağını (McGuire, 1985) ve kaynağın alıcıya ödül ve ceza uygulayacağına olan inanç doğrultusunda itaati sağlayacağını (Petty ve Cacioppo, 1996) ifade eder. Kelman'ın (1961) sosyal etki teorisinde ele aldığı bu üç faktörden itaat kaynağın otoritesi, içselleştirme kaynağın güvenilirliği, özdeşleşme ise kaynağın çekiciliği ile ilişkilendirilmiştir (Perloff, 2003: 152). Ünlü kullanılan reklamların etkinliği ise sosyal etki süreciyle ilişkilendirilebilmektedir (Kamins, 1990). Bu üç aşamadan özdeşleşme ve içselleştirme reklamlarda ünlü kullanımında uygulanabilirliği daha uygun değişkenlerdir. Zira kişinin ünlü kişiyle bağ kurması itaat bağlamında çok anlamlı değildir çünkü bireyin yapacağı tercihlerde ünlü kişi tarafından onanma arzusu yoktur ya da onun normatif etkisini üzerinde hissetmez (Kapitan ve Silvera, 2016). İçselleştirme ise kişinin ünlünün eylem ya da inançlarının güvenilir olarak algılanması dolayısıyla kişinin kendi değer sistemiyle uyumlu olduğundan o ünlünün tutum ya da davranışını benimsemesidir. Kelman'a (1961) göre etkileyen konumundaki kişinin özellikleri önemlidir fakat kritik olan güvenilirliktir. İçselleştirmenin gerçekleşmesi için tüketiciler mesajla bütünleşmeli ve ünlü kişi de inanılır, dürüst ve güvenilir olarak algılanmalıdır (Biswas vd., 2009; Kapitan ve Silvera, 2016).

\section{Özdeşleşme (Identification)}

Özdeşleşme kavramına ilişkin birçok tanım vardır. Herbert Kelman, Kenneth Burke, Albert Bandura gibi teoristler farklı bağlamlarda da olsa çalışmalarında özdeşleşmeyi ele almışlardır. Hepsinin özdeşleşme tanımının ortak yanı, özdeşleşme sürecinde bireyin bir başka kişi ya da varlığın özelliklerini, tutumlarını ya da davranışlarını benimsediği ya da onun karakteristiklerini kendisininkiyle birleştirdiği yönündedir. İnsanların bir başka kişi ya da grupla özdeşleşmesindeki amaç ise kişilerle bağ kurmak, potansiyellerini maksimize etmek ya da kendilerini gerçekleştirmektir (Hoffner ve Buchanan, 2005). Kelman'a (1961) göre özdeşleşme iknanın bir sürecidir ve kişinin o kişi ya da grup gibi olmak istediğinden başka kişi ya da grubun davranışını benimsemesi olarak tanımlanabilir. Kişi bir başka kişi ya da grubun davranışını benimser çünkü bu davranış bu kişi ya da grupla olan tatmin edici, kendini tanımlayan ilişki ile ilgilidir.

Kitle iletişim literatürü bir karakterle özdeşleşmeyi, o karakteri sevme ya da kendine benzer bulma vb. ile ilişkilendirir. Bu alandaki literatür bireyin medya karakterleriyle özdeşleşmesi ve para-sosyal etkileşimi kapsamında sıklıkla çalışma konusu olmuştur (v. Feilitzen ve Linne, 1975; Giles, 2000; Eyal ve Rubin, 2003; Hoffner, 1996; Hoffner ve Buchanan, 2005). Hoffner'in (1996) ifade ettiği şekliyle "özenerek özdeşleşme" bireyin bir başka birey gibi olmayı arzu ettiği ya da olmaya çalıştığı psikolojik bir süreçtir. Zira Bandura'nın (2001) söylediği de budur: medya karakterini rol model alma salt davranış taklidinin ötesinde bir şeydir; tutum, değer, arzu ve diğer özelliklerini medya karakterine uyacak şekilde değiştirmektir. 
Özdeşleşmenin, kaynak konumundaki kişinin sevilme ve çekicilik gibi duygusal özellikleriyle de güçlü bir ilişkisi vardır. Tüketicinin ünlü kişiye ilişkin algıladığı benzerlik, aşinalık, sevilirlik ve çekicilik ünlü kişi gibi olma isteğinde belirleyicidir. Özdeşleşmede birey, ünlü kişi gibi olmak, ünlünün reklamını yaptığı ürünü kullanmak dâhil onun davranışlarını taklit etmek ister. Bir başka deyişle tüketicinin ünlüyle özdeşleşmesi bu özelliklerde algılanan olumlu çıkarımlara bağlıdır (Kelman, 1961; Basil, 1996; Nam-Hyun Um, 2013; Kapitan ve Silvera, 2016). Kişi kendisini ünlüyle özdeşleştirdiği ölçüde mesaja yönelik olumlu yönde tutum ve davranış yönelimi görülecektir (Basil, 1996).

\section{Literatür Taraması ve Araştırma Hipotezlerinin Geliştirilmesi}

Özdeşleşme konusu iletişim literatüründe sıklıkla medya karakterleriyle özdeşleşme bağlamında ele alınmıştır (v. Feilitzen ve Linne, 1975; Hoffner, 1996; Eyal ve Rubin, 2003; Hoffner ve Buchanan, 2005). Ünlüyle özdeşleşme konusu ise sınırlı sayıda çalışmaya konu olmuştur (Friedman ve Friedman, 1979; Brown ve Basil, 1995; Basil, 1996; Daneshvary ve Schwer, 2000; Fraser ve Brown, 2002; Nam-Hyun Um, 2013; Jin ve Phua, 2014). İdealize edilmiş medya kişilikleri gibi kişinin kendisinden sosyo-psikolojik anlamda uzak olan kişilerle sosyal kıyasa gitmesi halinde model alınan kişinin yaşam standardına ilişkin abartılı ve gerçekçi olmayan, yüksek beklentilere girmesi, dolayısıyla gerçek ve ideal arasında artan boşluk; bir başka ifadeyle bireyin kendisini daha yüksek sosyal konumda biriyle kıyaslaması daha fazla materyalist sahiplik isteği ve tüketim niyetiyle ilişkilendirilmiştir (Sirgy, 1998; Ogden ve Venkat 2001). Genç tüketiciler üzerinde yapılan araştırmalara ilişkin ampirik bulgular da genç bireyin kendisine anne, baba gibi doğrudan rol model seçtiği gibi favori medya karakterlerini de dolaylı rol modelleri seçebildiğini ve bunları marka seçimi, marka değiştirme ve tüketici şikâyet bildiriminde referans aldıklarını ortaya koymuştur (Martin ve Bush, 2000). Caughey'in çalışması da (1985) genç bireyin ünlüye imrendiği ve onu ideal imaj olarak gördüğünü, idol olarak gördüğü bu karakterinkine benzeyecek şekilde kişilik özelliklerini geliştirdiğini ya da düzelttiğini ifade etmiştir. İdolünü taklit etmek isteyen birey fiziksel görüntüsünü, yeteneklerini, değerlerini ve tutumlarını değiştirmek isteyecektir. Fiziksel çekicilik ve uyum hipotezi modeliyle ortaya konan bulgular bir yana (Kahle ve Homer, 1985; Kamins, 1990), bireyler ideal kimliğe erişmek adına idol olarak gördükleri ünlülerin reklamında yer aldığı markaları daha etkileyici bulmaktadırlar; bir anlamda birey sahip olmadığı belirli bir imajı telafi gereksinimi olarak görmektedir (WoodruffBurton ve Elliott 2005). Lafferty ve Goldsmith (1999) de genç tüketicilerin eğlence endüstrisinden bir ünlünün ya da sporcu bir ünlünün reklamında oynadığı ürünleri satın almaya daha istekli olduklarını ortaya koymuşlardır. Öte yandan, daha önce yapılan çalışmalarda da ortaya konduğu üzere benzerlik ve uyum da tutum geliştirme ve iknada son derece belirleyicidir ve benzerlik-çekicilik yaklaşımından hareketle birey kendisine benzer bulduğu kişilere daha olumlu tepki vermeye eğilimlidir (Byrne, 1971; Klaus ve Bailey, 2008). Değer, inanç, düşünce ve benlik tanımına ilişkin algılanan benzerlik kişiler arasında çekicilik algısını da beraberinde getirecektir; yani kendisini benzer bulduğu kişi bireye daha çekici gelecektir (Obot, 1988; Simpson vd., 2000; Fraser ve Brown, 2002). Özdeşleşmeye ilişkin özenen ve benzerliğe bağlı iki tip özdeşleşmeden bahsedilmesinden hareketle de (v. Feilitzen ve Linne, 1975; Hoffner, 1996; Hoffner ve Buchanan, 2005; Chory ve Yanen, 2005), aşağıdaki hipotezler geliştirilmiştir:

\section{$H_{1}$ : Bireyin reklamda yer alan ünlü ile özdeşleşmesi (özenerek ve benzerliğe bağlı); \\ $H_{1 a}$ : Ünlünün yer aldığı reklama yönelik tutumunu olumlu yönde etkilemektedir \\ $H_{1 b}$ : Reklamda yer alan markayı satın alma niyetini olumlu yönde etkilemektedir}


Ünlü-marka arasındaki uyumun reklama ve markaya yönelik tutum ve satın alma niyeti açısından reklam etkinliği de çeşitli ampirik çalışmalarla ortaya konmuştur (Kahle ve Homer, 1985; Kamins, 1990; Schaeffer ve Keillor, 1997; Rice vd., 2012). Choi ve Rifon ise (2012) alternatif bir bakış açısıyla uyumu ünlü imajı ve tüketicinin benlik algısı arasında incelemiş ve bu uyumun reklamda ünlü kullanımının etkinliğinde önemli bir katkısı olduğunu ortaya koymuştur. Bu bulgulardan hareketle;

$\mathrm{H}_{2}$ : Reklama yönelik tutumun satın alma niyeti üzerinde olumlu etkisi vardır.

$H_{3}$ : Reklamdaki ünlü-ürün uyumunun

$H_{3 a}$ : Özdeşleşmenin reklama yönelik tutum üzerindeki etkisini güçlendiren ılımlaştırıcı (moderatör) rolü vardır

$H_{3 b}$ : Özdeşleşmenin satın alma niyeti üzerindeki etkisini güçlendiren ılımlaştırıcı (moderatör) rolü vardır

$H_{3 c:}$ Reklama yönelik tutumun satın alma niyeti üzerindeki etkisini güçlendiren ılımlaştırıcı (moderatör) rolü vardır.

\section{Şekil 1: Araştırma Modeli}

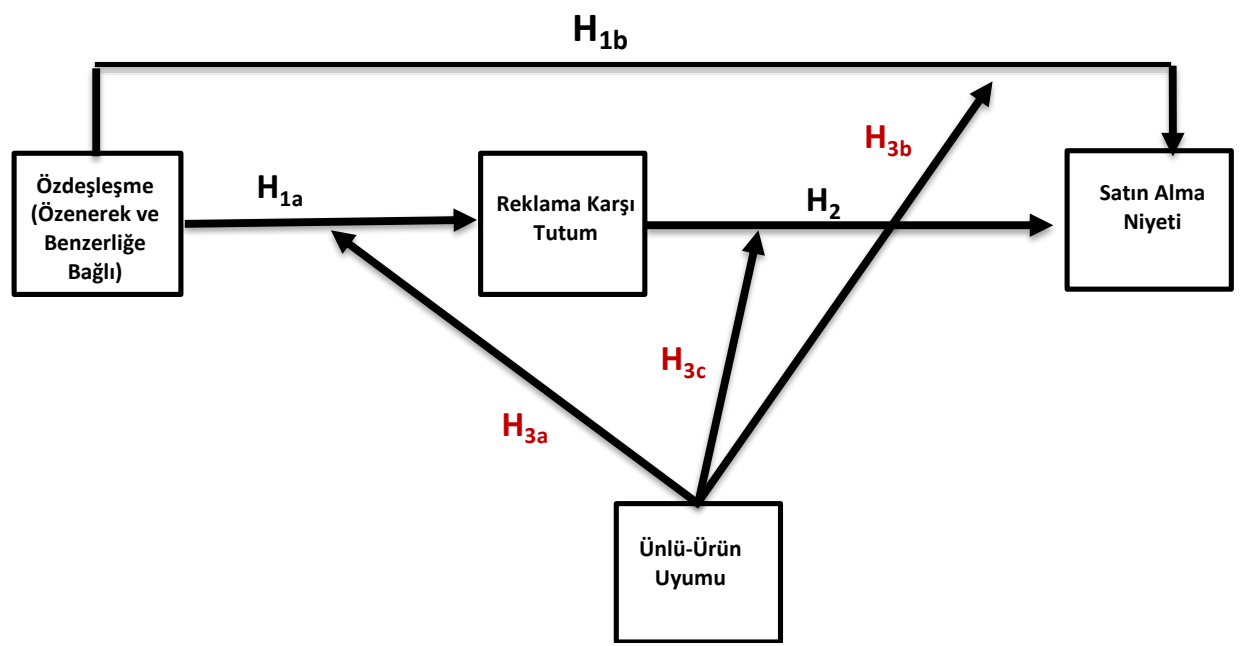

*Markaya Karşı Tutum ve Ünlünün Sevilirliği yapılarına kontrol değişkenleri olarak yer verilmiş ve model testinde bağımsız değişkenlerle etkileşimleri ve bağımlı değişkenlerdeki etkileri de hesaba katılmıştır.

\section{Araştırmanın Yöntemi}

\subsection{Prosedür}

Araştırma kapsamında ortaya konan model ve hipotezlerin ampirik olarak testi nicel olarak desenlenmiş olan araştırma ile gerçekleştirilmiştir. Araştırma verileri, çevrimiçi (online) tasarlanmış anket ile sosyal medya (Facebook) üzerinden, 18 yaş üzerindeki 642 katılımcıdan, iki Facebook kullanıcısı profilinden bir hafta arayla her bir reklam versiyonuna ilişkin anket linkinin paylaşılması suretiyle toplanmıştır.

Çalışmaya konu ünlüler bilinirlikleri ve güncel popülariteleri gözetilerek ve 2016 yılında Türkiye'de yapılmış bir çalışmayla da en popüler kişiler olarak ortaya konmuş olan (Sarıkaya ve Barutçu, 2016) futbolcu Arda Turan ve şarkıcı Hadise olarak belirlenmiştir. Sporcu ünlü, sporcu 
olarak sahip oldukları yetenekleri ile çeşitli müsabakalarda kazandıkları başarılarla edindikleri kahraman statüsü ve medyada yer almak suretiyle edindikleri ünlü bilinirliğinin bir bakıma birleşimi olarak tanımlanabilir (Braunstein ve Zhang, 2005). Sporun salt oyundan profesyonel eğlenceye dönüşmesi itibariyle spor pazarlamacıları sporcu ünlüler aracılığıyla eğlence endüstrisinin fırsatlarından kendileri de istifade etmeye başlamışlardır (Boyd ve Shank, 2004; Martin ve Bush, 2000; Peetz vd., 2004). Boon ve Lomore (2001) da yaptıkları çalışmada genç bireylerin $\% 75$ inden fazlasının özellikle şarkıcı ve film yıldızı ünlülerden bir ya da daha fazlasından hayatlarının belli bir döneminde oldukça fazla düzeyde etkilendiklerini ortaya koymuşlardır. Denge teorisi (Heider, 1958) ile paralel değerlendirilecek olursa eğer birey ünlü şarkıcının seslendirdiği müzik ile uzun süreli bağ kurabiliyorsa ve olumlu duygular besliyorsa, bu durum ünlüye olan sevgisini de güçlendirecektir (Caldwell ve Henry, 2005).

Bu çalışmada, ünlülerin marka uyumunu ortaya koymak üzere ise bu ünlülerin hali hazırda yer aldıkları ya da daha önce yer almış oldukları reklamlar taranmıştır. Katılımcılardan elde edilecek geri dönüşleri maksimize edebilmek ve ekolojik geçerliliği sağlamak için hipotetik reklamlar yerine gerçek reklamlar tercih edilmiştir.

Ana araştırma öncesi ünlü-ürün uyumunu ortaya koymak üzere ön araştırma gerçekleştirilmiştir. Araştırma basılı formlar aracılığıyla uygulanmıştır. Bu kapsamda erişim kolaylığı bulunan 32 katılımcıya (16 kadın ve 16 erkek) seçilen reklamları iki ünlü ve 1 ile 6 arasında değişen skorlarda (1: en uyumlu; 6: en uyumsuz), bu ünlülerin imajıyla algıladıkları uyum düzeyine göre derecelendirmeleri istenmiştir. Buna göre her bir ünlü için taranan reklamlar arasında ön araştırma için seçilen reklamlar ve ön araştırma sonuçları Tablo 1'de sunulmuştur:

Tablo 1: Ön Araştırma Sonucu

\begin{tabular}{lllll}
\hline & ARDA TURAN & \multicolumn{3}{l}{ HADiSE } \\
\hline Sira & Reklam & $\boldsymbol{\Sigma}$ Skor & Reklam & $\boldsymbol{\Sigma}$ Skor \\
\hline 1 (en uyumlu) & Nike & 82 & Penti & 57 \\
2 & Opet & 99 & Avon & 78 \\
3 & DeFacto & 104 & Nestle & 118 \\
4 & Simit Sarayı & 122 & Fanta & 127 \\
5 & Coca Cola & 124 & Sirma & 141 \\
6 (en uyumsuz) & Türkiye Finans & 141 & Türk Telekom & 151 \\
\hline
\end{tabular}

Araştırma sürecinin yönetimini kolaylaştırmak adına, ön araştırmada belirlenen altı reklam arasından en yüksek uyumda iki ve en düşük uyumda iki reklam olmak üzere ana araştırmada kullanılacak dörder reklam seçilmiştir. Bunlar ise 1 en yüksek uyum 4 en düşük uyumu temsil etmek üzere Arda Turan: Nike (1), Opet (2), Simit Sarayı (3) ve Türkiye Finans (4); Hadise: Penti (1), Avon (2), Sırma (3) ve Türk Telekom (4).

\subsubsection{Veri Toplama Aracı}

Araştırmaya konu yapılara ilişkin ölçekler geçerliliği ve güvenilirliği geçmiş çalışmalarda ortaya konan ölçekler olup; Ürün-Ünlü Uyumu, Schaefer ve Keillor'ın (1997) çalışmasından alınmış ve 5'li Likert tipi (1=Kesinlikle Katılmıyorum, 5=Kesinlikle Katılıyorum) yedi soru ile ölçülmüştür. Özenerek Özdeşleşme yapısı, Hoffner ve Buchanan'ın (2005) çalışmasından uyarlanmış ve $5^{\prime}$ li Likert tipi (1=Kesinlikle Katılmıyorum, 5=Kesinlikle Katılıyorum) beş soru ile ölçülmüştür. Benzerliğe Bağlı Özdeşleşme yapısı, Chory-Assad ve Yanen'in (2005) ve Schuh'un 
(2008) çalışmasından uyarlanmış ve 5'li Likert tipi altı soru ile test edilmiştir. Reklama Karşı Tutum, Miniard, Bhatla ve Randall'ın (1990) çalışmasından; Satın Alma Niyeti, Till ve Bussler'in (2000) çalışmasından uyarlanmış ve dokuzlu semantik yapıdaki beş soru ile ölçülmüştür. Ünlüye Karşı Tutum (Ünlünün Sevilirliği), Bergkvist vd.'nin (2016) tanımındaki gibi, bireyin bir ünlüyü sevme ya da sevmemesi şeklindeki olumlu ya da olumsuz değerlendirmesi olarak kavramsallaştırılmış ve ünlünün sevilirliği şeklinde operasyonelleştirilmiş (Schaefer ve Keillor, 1997) ve kontrol değişkeni olarak dokuzlu semantik yapıdaki üç soru ile ölçülmüştür. Markaya Karşı Tutum, Till ve Busler'in (2000) çalışmalarındaki gibi dokuzlu semantik yapıda üç sorulu ölçek ile ölçülmüş ve modelde kontrol değişkeni olarak yer verilmiştir.

Araştırma modeline dâhil edilmemekle birlikte reklamlarda yer alan ünlülerin kaynak karakteristiklerine ilişkin katılımcı algısını ölçmek üzere kaynağın güvenilirliği, çekiciliği, benzerliği ve aşinalığına ilişkin sorular da sorulmuştur (Ohanian, 1990; Oliver ve Bearden, 1985; Schaefer ve Keillor, 1997).

\subsubsection{Pilot Çalışma}

Ana araştırma öncesi belirlenen reklamların her biri için 30'ar kişilik gruplarda bir pilot araştırmaya tabi tutulmuştur. Ifadelerin anlaşılırlığı ve yapıların geçerlilik ve güvenilirlikleriyle birlikte uzman görüşünde de önerildiği gibi, marka ve ünlünün anket formunda yer alma sırasında sıralama etkisinin (order-effect) olup olmadığı da test edilmiştir. Buna göre veri toplama aracında eş ağırlığı (counterbalance) tesis ederek katılımcıların şartlı refleks ile sıralama etkisine bağlı yanıt verip vermediklerini görmek adına veri toplama aracında ünlü ve markaya ilişkin görsel ve soruların sırası değiştirilmiştir. Bir versiyonda ünlünün fotoğrafı ve onunla ilgili soruları marka, reklam, uyum, özdeşleşme ve satın alma boyutuna ilişkin sorular yer almıştır. Diğer versiyonda ise önce marka görseli ve ona ilişkin sorular, akabinde ünlünün fotoğrafı, ünlüyle ilgili sorular, reklam, uyum, özdeşleşme ve satın alma boyutuna ilişkin sorular yer almıştır.

Verilerin toplanması sonrası ünlü ve markanın anket formunda yer alma sırasının yarattığı farka iliş̧in bağımsız örneklem t-testi analiz sonuçları ifadeler arasında iki grup arasında ortalama açısından istatistiki olarak anlamlı bir fark göstermemiştir $(n=119 ; p>.05)$. Ancak sıralama etkisinin olup olmadığı ana araştırmada da gözetilmiş ve her bir reklam için iki versiyonda soru sorulmuştur.

Ana veri sosyal medya (Facebook) olmak üzerinden çevrimiçi ortamda hazırlanan ankette, ünlülerin yer aldığı reklamların videolarına Youtube erişim linkleri verilmek suretiyle sesli ve görüntülü olarak izletilerek toplanmıştır. Nitekim reklamlarda ünlü kullanımının ikna etkisi sıklıkla basılı reklam, zorunlu maruz bırakma gibi geleneksel deneysel tasarımlarıyla ölçülürken artık yerini alternatif ve daha etkin bir araştırma mecrası olan dijital mecraya bırakmaktadır (Bergkvist ve Zhou, 2016).

Toplanan veriler öncelikle kayıp verinin, aykırı değerler ve dikkatsiz katılımcıların olup olmaması açısından değerlendirilmiştir. Soruların tamamına aynı skoru işaretleyen vb. dikkatsiz kullanıcıların da veri setlerinden çıkarılması neticesinde veri setinde 513 kullanılabilir veri üzerinden analiz yapılmıştır.

\subsection{Katılımcı Profili}

Toplanan kullanılabilir 513 katılımcı demografik verisine ilişkin tablo aşağıda sunulmaktadır. Yaş ortalaması 34 olan katılımcıların \%59'u kadın $(n=303)$ iken \%41'i ise erkektir $(n=210)$. 


\subsection{Verilerin Analizi}

Açıklayıcı faktör analizi ve güvenilirlik analizi sonrası faktör yapılarına ilişkin ölçüm modelinin geçerliliği AMOS yazılımı kullanılarak doğrulayıc faktör analizi yapılmak suretiyle test edilmiştir. Analiz sonrası nihai modele ilişkin uyum iyiliği değerleri incelenmiş ve değerlerin kabul sınırlarında olduğu görülmüştür $\left(\chi^{2}=861.314 ; d f=405 ; \chi^{2} / d f=2.127 ; C F I=0.97 ; G F I=\right.$ $0.90 ; T L I=0.97 ; \mathrm{NFI}=0.94 ; R M S E A=0.047$ ). (Tabachnick ve Fidell, 2001; Hu ve Bentler, 1999; Marsh ve Hocevar 1985).

Verilere ilişkin yakınsak (convergent) ve ayırıcı (discriminant) geçerlilik testini gösteren korelasyon değerleri, tanımlayıcı istatistikler, Kompozit/Birleşik Güvenilirlik (Composite Reliability-CR) ve Ortalama Açıklanan Varyans (Average Variance Extracted-AVE) bulguları ise aşağıdaki Tablo 3'te raporlanmıştır. Tablodan da görülebileceği gibi her bir yapının AVE değeri 0.50 'den yüksektir ve bu yakınsak geçerliliğin tesis edildiğini gösteren bir bulgudur (Fornell ve Larcker, 1981). Yapılar arası korelasyon katsayısının yüksek olmaması $(<0.90)$ ve her bir yapının AVE değerinin karekökünün yapılar arası en yüksek korelasyon katsayısından daha yüksek olması da ayırıcı geçerliliğin sağlandığını göstermektedir (Fornell ve Larcker, 1981).

Tablo 2: Gizil Yapılara iliş̧kin Korelasyon, Ortalama, Standart Sapma ve CR/AVE Değerleri

\begin{tabular}{llllllll}
\hline & SEV & MATU & REKTU & UYUM & ÖZEN & BENZ & SAN \\
\hline SEV & 1 & $.148^{* *}$ & $.397^{* *}$ & $.294^{* *}$ & $.305^{* *}$ & $.285^{* *}$ & $.287^{* *}$ \\
MATU & .021 & 1 & $.331^{* *}$ & $.150^{* *}$ & $.095^{*}$ & $.097^{*}$ & $.603^{* *}$ \\
REKTU & .157 & .109 & 1 & $.378^{* *}$ & $.309^{* *}$ & $.250^{* *}$ & $.516^{* *}$ \\
UYUM & .086 & .022 & .143 & 1 & $.507^{* *}$ & $.360^{* *}$ & $.249^{* *}$ \\
ÖZEN & .093 & .009 & .095 & .257 & 1 & $.682^{* *}$ & $.204^{* *}$ \\
BENZ & .081 & .009 & .062 & .130 & .465 & 1 & $.211^{* *}$ \\
SAN & .082 & .363 & .266 & .062 & .041 & .044 & 1 \\
Ort & 4.85 & 5.83 & 4.98 & 2.17 & 1.61 & .1 .59 & 4.48 \\
S & 2.18 & 2.11 & 2.19 & .71 & .77 & .78 & 2.24 \\
CR & 0,94 & 0,96 & 0,97 & 0,89 & 0,93 & 0,96 & 0,97 \\
AVE & 0,84 & 0,90 & 0,85 & 0,55 & 0,78 & 0,79 & 0,92 \\
\hline
\end{tabular}

** .01 düzeyinde anlamlı bir korelasyon vardır; * .05 düzeyinde anlamlı bir korelasyon vardır. İtalik yazı biçimi ile gösterilen değerler korelasyon değerlerinin kareleridir.

SEV = Ünlünün Sevilirliği; MATU = Markaya Karşı Tutum; REKTU= Reklama Karşı Tutum; UYUM=Ünlü-Ürün Uyumu; ÖZEN= Özenerek Özdeşleşme; BENZ=Benzeşerek Özdeşleşme; SAN = Satın Alma Niyeti

\section{Gruplar Arası Farklılıkların Testi}

Verilerin analizine geçmeden önce, öncelikle, kadın ve erkek ünlünün yer aldığı reklam versiyonlarının tek veri setinde değerlendirilebilirliğini incelemek üzere ortaklama prosedürü (pooling procedure) işlenmiş ve bunun için, daha önce MacKenzie vd. (1986) ve Bergkvist vd. (2016) yaklaşımıyla bağımsız değişkenlere ilişkin varyanslar arasında anlamlı farklılık bulunup 
bulunmadığı Levene testi ile test edilmiştir. Varyansların homojenliğine ilişkin test bulguları incelendiğinde ise benzerliğe bağlı özdeşleşme yapısında varyansın homojenliğinin sağlanamadığı görülmüştür $(p=.001<.05)$. Bu çalışmada uyum ve özdeşleşme etkisine her bir ünlü veya marka üzerinden ziyade kavramsal düzeyde bakıldığından cinsiyetler arasındaki bu ayrışma gözardı edilmiş ve iki veri seti birlikte değerlendirilmiştir.

Veri setlerinin birleştirilmesi aşamasında tüm ünlü-marka reklam versiyonlarının birlikte değerlendirilebilirliğini ortaya koymak üzere de bağımsız değişkenlere ilişkin varyanslar arasında anlamlı farklııı bulunup bulunmadığı Levene testi ile test edilmiştir. Yapılan test sonucunda reklama karşı tutum, özenerek özdeşleşme ve benzerliğe bağlı özdeşleşme, ünlünün sevilirliği bağımsız değişkenleri için varyans homojenliği sağlanırken ( $p>05$ ) markaya karşı tutum değişkeninde sağlanamamıştır $(p<.05)$. Söz konusu yapı veri setinde kontrol değişkeni olarak ele alındığından ve gerçek marka ve ünlülerin çalışma konusu olması itibariyle markaya karşı tutum boyutundaki ayrışma göz ardı edilmiş ve tüm ünlü-marka versiyonları birlikte değerlendirilmiştir.

Verinin temel analizler öncesi hazırlanması sürecinde bir sonraki aşamada ise, araştırmaya konu ünlü-marka uyumunun ön testte ortaya konduğu gibi uyum düzeylerini verip vermediği ANOVA testi ile sınanmıştır. Grup ortalamaları dört grup arasında anlamlı ve öngörüldüğü uyum düzeylerinde farklılık bulunmuştur ( $p=.01<.05)$.

\section{Yapılar Arasında Sıralama Etkisine Bağlı Fark Testi}

İki veri toplama tekniği açısından (ünlü ve markanın ankette yer alma sırası) sıralama etkisinin olup olmadığını test etmek için iki teknikle toplanan veri setleri arasında bağımsız örneklem t-testi yapılmıştır. Markaya yönelik tutum dışında $(p=.003<.05)$, yapıların ortalamaları arasında sıralama etkisine bağlı anlamlı bir farklııı bulunmamaktadır ( $p>05$ ).

\subsection{Bulgular}

Çalışmanın bu kısmında, hipotezlerin geliştirilmesi aşamasında ortaya konan, Şekil 1 de sunulan araştırma modelinin testi yapılmıştır. Birinci aşama hipotez testinde özdeşleşmenin (özenerek ve benzerliğe bağlı) reklama karşı tutum ve satın alma niyeti üzerindeki etkisi incelenmiştir. İlgili analiz bulguları Tablo 3'de sunulmuştur.

Tablo 3: Model Testine Ilişkin Sonuçlar

\begin{tabular}{|c|c|c|c|c|}
\hline & 1erilen Model & & Final Model & \\
\hline Yol & $\begin{array}{c}\text { Std } \\
\text { Olmayan } \\
\text { Yol } \\
\text { katsayısı }\end{array}$ & $\begin{array}{c}\text { Std } \\
\text { Yol } \\
\text { katsayısı }\end{array}$ & $\begin{array}{l}\text { Std Olmayan } \\
\text { Yol katsayısı }\end{array}$ & $\begin{array}{c}\text { Std } \\
\text { Yol katsa) }\end{array}$ \\
\hline Özdeşleşme->Reklama &, $343^{*}$ & 127 & ,416** & 153 \\
\hline $\begin{array}{l}\text { Benzerliğe Bağlı Özdeşleşme- } \\
>\text { Reklama Karşı Tutum }\end{array}$ & 114 & ,040 & - & - \\
\hline $\begin{array}{l}\text { Markaya Karşı Tutum ->Reklama } \\
\text { Karşı Tutum }\end{array}$ & ,288** & 283 & ,289** & ,284 \\
\hline
\end{tabular}




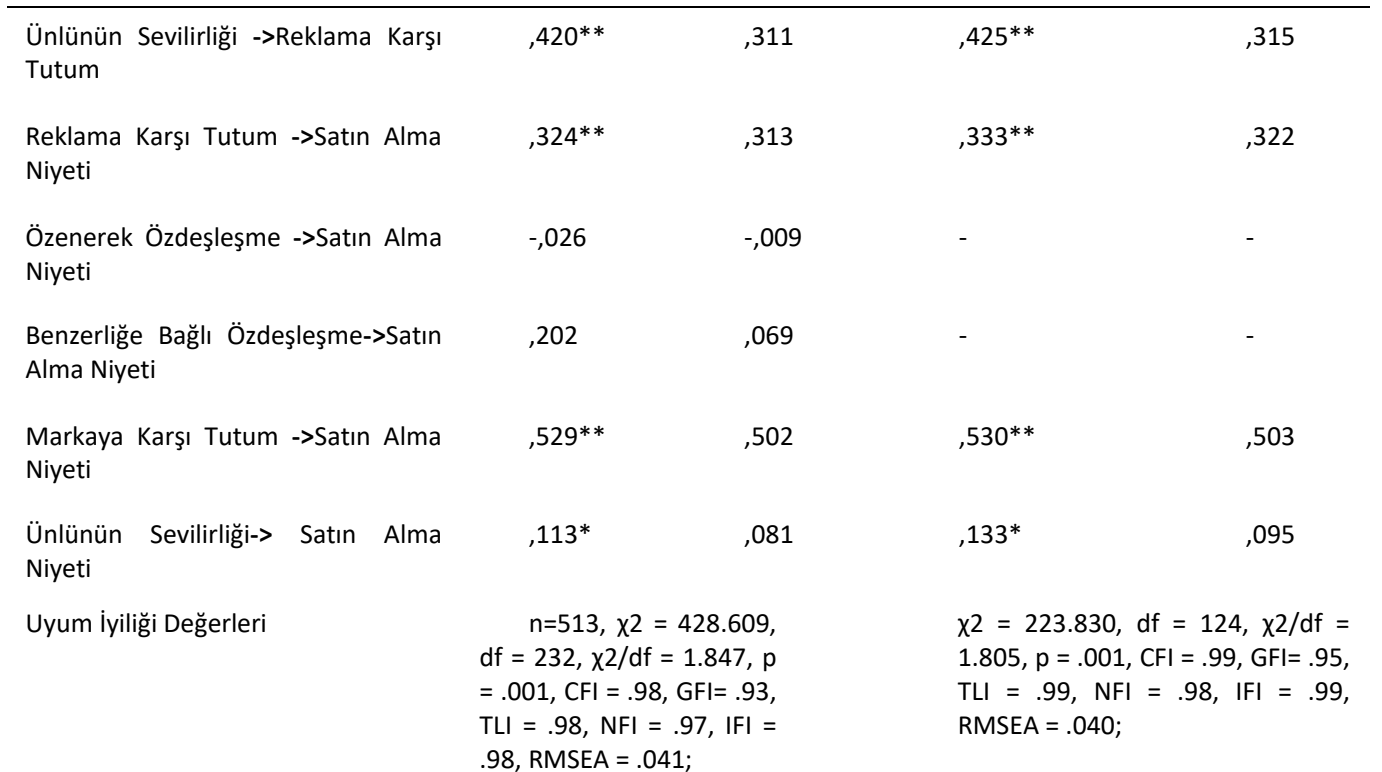

${ }^{* *} \mathrm{p}<.01,{ }^{*} \mathrm{p}<.05$ ifade etmektedir.

Yapısal Modelin testine ilişkin analiz çıktısı incelendiğinde, özenerek özdeşleşme boyutunun reklama karşı tutumu olumlu yönde etkilediği ( $\mathrm{H}_{1 a}$ desteklendi), satın alma niyetini ise dolaylı olarak reklama karşı tutum aracılığında etkilediği görülmektedir $\left(\mathrm{H}_{1 \mathrm{~b}}\right.$ kısmen desteklendi). Öte yandan benzerliğe bağlı özdeşleşmenin reklama karşı tutum ve satın alma niyetinde bir belirleyiciliği olmadığı gözlenmiş olup ilgili hipotezlerin ünlüyle benzerlik algısında desteklenmediği görülmüştür. Reklama karşı tutum ise öngörüldüğü gibi satın alma niyetini olumlu yönde etkilemektedir ( $\mathrm{H}_{2}$ desteklendi).

Choi ve Rifon'un (2012) model testi yaklaşımında izledikleri prosedür izlenmiş ve önerilen modeli daha sade ve rafine bir hale getirmek için istatistiki olarak anlamlı bulunmayan yollar ikinci aşama analizlerle teker teker modelden çıkarılmış ve ki-kare değişimi incelenmiştir. Bahse konu üç yol olan (1) özenerek özdeşleşmeden satın alma niyeti, (2) benzerliğe bağlı özdeşleşmeden reklama karşı tutum, (3) benzerliğe bağlı özdeşleşmeden satın alma niyeti yolları teker teker modelden çıkarılmış ve önerilen modeldeki ki-kare değişimi karşılaştırılmış ve anlamlı bir değişme olmadığı görülmüştür. (1) $\Delta \chi 2=.02, \Delta \mathrm{df}=1, \mathrm{p}>.05$; (2) $\Delta \chi 2=.39, \Delta \mathrm{df}=$ $1, p>.05 ;$ (3) $\Delta x 2=1.66, \Delta d f=1, p>.05$. nihayetinde model uyum iyiliğine anlamlı bir katkı sunmayan bu üç yol modelden çıkarılmıştır. Bir sonraki aşamada önerilen model ve revize edilmiş halinin ki-kare farkları incelenmiş ve farkın anlamlı olduğu görülmüştür $(\Delta x 2=$ $.204,779, \Delta d f=108, p<.05)$. Ayrıca revize modelin uyum iyiliği değerlerinin de önerilen modelden daha iyi değerlere sahip olduğu görülmektedir. Dolayısıyla ikinci aşama hipotez testine revize model üzerinden devam edilmiştir.

İkinci aşama hipotez testinde ünlü ve ürün arasında algılanan uyum düzeyinin yukarıda ortaya konan etkilerde ne şekilde ve ne düzeyde belirleyici olduğuna dair çoklu grup moderatör analizi yapılmıştır. Düşük ve yüksek ünlü-ürün uyumundaki iki grup arasında yolların (path) sabit tutulduğu ve serbest bırakıldığı iki model arasında anlamlı bir fark bulunmuştur $(\Delta \times 2=$ $28,595, \Delta d f=20, p=.096<.10)$. Bir başka ifadeyle özdeşleşme, markaya karşı tutum ve ünlü- 
nün sevilirliğinin reklama karşı tutum ve satın alma niyeti üzerindeki etkisi, reklamdaki ünlüürün arasında algılanan uyumun düzeyine göre model düzeyinde farklılık göstermektedir. Söz konusu gruplarda yapısal modelin testine ilişkin bulgular şu şekildedir ( $\chi 2=422.288 \mathrm{df}=252$, $\chi 2 / \mathrm{df}=1.676, \mathrm{p}=.001, \mathrm{CFI}=.98, \mathrm{TLI}=.98, \mathrm{NFI}=.96, \mathrm{IFI}=.98, \mathrm{RMSEA}=.036$ ):

Tablo 4: Uyum Düzeyine Göre Standardize Olmayan Yol Katsayıları

\begin{tabular}{|c|c|c|c|c|c|c|}
\hline \multirow[b]{2}{*}{ Yol } & \multicolumn{4}{|c|}{ Yüksek Uyum } & \multicolumn{2}{|c|}{ Düşük Uyum } \\
\hline & $\begin{array}{l}\text { Yol } \\
\text { katsayısı }\end{array}$ & $\begin{array}{l}\text { Std } \\
\text { Hata }\end{array}$ & $\mathbf{t}$ & $\begin{array}{l}\text { Yol } \\
\text { katsayısı }\end{array}$ & $\begin{array}{l}\text { Std } \\
\text { Hata }\end{array}$ & $t$ \\
\hline $\begin{array}{l}\text { Özenerek Özdeş- } \\
\text { leşme @?Reklama } \\
\text { Karşı Tutum }\end{array}$ &, $446 * *$ & 150 & 2,982 & ,428* & 180 & 2,378 \\
\hline $\begin{array}{l}\text { Markaya Karşı } \\
\text { Tutum ? ?Reklama } \\
\text { Karşı Tutum }\end{array}$ &, $316 * *$ & ,055 & 5,736 &, $243 * *$ & ,069 & 3,540 \\
\hline $\begin{array}{l}\text { Ünlünün Sevilirliği } \\
\text { ?Reklama } \quad \text { Karşı } \\
\text { Tutum }\end{array}$ &, $534 * *$ & ,077 & 6,924 & ,255* & 100 & 2,547 \\
\hline $\begin{array}{l}\text { Reklama Karşı } \\
\text { Tutum @]Satın Alma } \\
\text { Niyeti }\end{array}$ &, $410^{* *}$ & ,055 & 7,422 &, $226 * *$ & ,061 & 3,713 \\
\hline $\begin{array}{l}\text { Markaya Karşı } \\
\text { Tutum @SSatın Alma } \\
\text { Niyeti }\end{array}$ & ,496** & ,053 & 9,341 &, $576 * *$ & ,063 & 9,206 \\
\hline $\begin{array}{l}\text { Ünlünün Sevilirliği } \\
\text { ? Satın Alma Niyeti }\end{array}$ & 114 & ,069 & 1,660 & 114 & ,082 & 1,396 \\
\hline
\end{tabular}

$\mathrm{n}_{Y}=299 ; \mathrm{n}_{\mathrm{D}}=214 ;{ }^{*} \mathrm{p}<.01,{ }^{*} \mathrm{p}<.05$ ifade etmektedir.

Reklama karşı tutum her iki uyum düzeyinde de satın alma niyetini olumlu yönde etkilemektedir. Uyumun düşük olması durumunda ise bu etki anlamlı bir şekilde azalmaktadır $\left(\mathrm{H}_{3 c}\right.$ desteklendi). Her iki uyum düzeyine ilişkin analiz çıktısı incelendiğinde, özenerek özdeşleşme boyutu reklama karşı tutumu olumlu yönde etkilerken bu etki azalan t değeriyle düşük uyum düzeyinde anlamlı bir şekilde azalmıştır ( $\mathrm{H}_{3 a}$ desteklendi). Bu yapının satın alma niyeti üzerindeki etkisi uyum düzeyinden bağımsız reklama karşı tutum aracılığı koşulunu gerektirmektedir; dolayısıyla dolaylı bir etki söz konusudur. Reklama karşı tutum aracılığındaki bu dolaylı etki düşük uyumda anlamlı bir şekilde azalmaktadır. Dolayısıyla özenerek özdeşleşme yapısı için $\mathrm{H}_{3 \mathrm{~b}}$ hipotezinin kısmen desteklendiğini söylemek mümkündür.

\section{Sonuç ve Tartışma}

Reklamlarda ünlü kullanımı, ünlünün bilhassa marka bilinirliği ve marka çağrışımları boyutları itibariyle reklama konu markanın değerini arttırması ve hedef kitlenin dikkatini reklama çekmesi açısından sıklıkla başvurulan bir reklam stratejisidir. Ünlünün hedef kitlede markaya yönelik tutum değişimi ve satın alma yönlü davranışsal çıktı yaratma etkisi de gözetildiğinde (Wang ve Scheinbaum, 2018) her ne kadar ünlü kullanımına önemli meblağlar yatırılsa da elde edilen çıktının bu maliyeti büyük ölçüde karşıladığı uygulamadan örneklerde de sıkça görülmektedir. Öte yandan, ünlü kullanımının reklam başarısının tek reçetesi olmadığı, dahası ünlü 
kullanımının beklenen olumlu etkiyi yaratmadığı ve beklenilenin altında getiri sağladığı durumlar da ortaya konmuştur (Taylor, 2016). Ampirik araştırmalar reklamda yer alan ünlü ile reklama konu ürün arasında uyum olması halinde bu etkinin daha da artacağını ortaya koymaktadır. Bu çalışmanın çıkış noktası da bireyin reklam tepkisini sadece, sıklıkla ele alınan ünlü-ürün uyumu bakımından ele almaktan ziyade soyut ve idealize edilmiş gösterge olarak değerlendirilebilecek özdeşleşme bakımından tüketici-ünlü uyumu bağlamında ele almak olmuştur.

Özdeşleşmeye ilişkin literatürde sıklıkla çocuk ve genç bireylerin medya karakterleriyle kurdukları bağı ele alınmış ve bu figürlerden önemli ölçüde etkilendikleri ortaya konmuştur ( $v$ Feilitzen ve Linne, 1975; Green ve Adams-Price, 1990; Tan ve Singh, 1995; Hoffner, 1996; Harwood, 1999; Chan ve Prendergast, 2008). Sosyal kimliğinin gelişimi sürecini yaşayan genç birey idol ya da kahraman olarak konumlandırdığı medya figüründen (özelde ünlüden) oldukça etkilenmektedir. Doğrudan rol model alınan anne babalar kadar ünlü ve çeşitli medya figürleri gibi dolaylı rol model olarak konumlandırılan figürler de genç bireylerin marka seçiminden markalar arası geçişine, satın alımın çeşitli aşamasında belirleyici olabilmektedir (Martin ve Bush, 2000). Genç bireylerin ünlü kişilerce reklamının yapıldığı ürünleri kullanma eğilimi gösterdiği geçmiş çalışmalarda ortaya konmuştur (Lafferty ve Goldsmith, 1999). Markaya, hedef kitle nezdindeki beğenilirliği, sevilirliği daha önemlisi tanınırlığıyla önemli düzeyde katkı sağlayan ünlülerin tüketici ile uyumunun reklam etkinliğine katkısının sınandığı bu çalışmada, ünlüyle kurulan özenme temelli bağların konu markalara ilişkin reklama ve satın alma niyetine katkısı olduğu ortaya konmuştur. Özenme, bireyin ideal benliğinin bir temsili olarak yorumlanabilirken benzerlik gerçek benlik temsili olarak değerlendirilebilir. İdealize bir kimlik atfedilen ünlülerin birey nezdinde algılandıkları konum itibariyle, bireyin ideal benliğe erişmede sevdiği ya da beğendiği ünlüyü aracı bir unsur olarak görürken onun gibi olabilmek adına yaptığı şeyleri yapıp, tutum ya da değerlerini dahi ona göre şekillendirme davranışı sergilemesi beklenebilecektir (Johar ve Sirgy, 1991). Bu bakış açısında ilgili literatürde ortaya konan bu ilişki, mevcut çalışmada da bireyin özendiği ünlünün yer aldığı reklamlara daha olumlu tutum beslerken ünlünün yer aldığı reklama konu markalı ürünü reklama yönelik tutum aracılığında daha fazla satın alma eğilimi de göstereceğini ortaya koymuştur (Park ve Lessig, 1977; Higgins, 1987; Johar ve Sirgy, 1991; Boon ve Lomore, 2001). Nitekim burada ünlülerin önemli düzeyde bir referans grup özelliğine de vurgu yapmak gerekir (Escalas ve Bettman, 2003). Birey ünlüyü ister rol model ister idol olarak görsün, ünlü ve onun anlam demetindeki unsurlar birey için ünlüye olan tutumu referansında daha olumlu çağrışımlar yapacaktır ve bu unsurlardan biri olarak konu markaya yönelik tutumu ve satın alma niyetini olumlu yönde besleyecektir (Byrne, 1971; Lafferty ve Goldsmith, 1999; Woodruff-Burton ve Elliott 2005; Halonen-Knight, E., ve Hurmerinta, 2010). İdeal kimlik yaklaşımıyla beslenen özenme güdüsünün ünlü ve yer aldığı reklama yönelik tutumu olumlu yönde etkilediği görülmektedir. Bireyin ünlüyle kurduğu ütopik düzlemdeki duygusal bağ, özenme çerçevesinde satın alma yönlü doğrudan etki göstermemekte ve reklama yönelik tutumla beslenmektedir. Öte yandan, bireyin ünlüyü gerçek benliğiyle ilişkilendirmesi olarak, benzerlik gibi görece daha somut göstergeler üzerinden kurduğu bağın anlamlı bir etkisi görülmemiştir. Bu açıdan değerlendirildiğinde tüketicinin ünlüyle gerçek benliğiyle örtüşen somut bağlar kurmadığı, kursa da bunun satın alma kararında belirleyici olmadığı söylenebilir. Bu durumu ise kollektivist bir kültür temsili olarak Türk bireyin ünlüyle arasında algıladığı güç mesafesine atfetmek mümkündür (Hofstede, 2001). Nitekim bu algı bireyin ünlüyü toplumsal yapıda ekonomik olarak en üst tabakada konumlandırmasından, reklamında yer aldığı ürünle arasındaki bağı da büyük ölçüde reklam getirisine atfedebilmesinden beslenmektedir. Bu anlamda tüketicinin satın alma kararında marka ve 
reklama yönelik algısının baskın rolü söz konusuyken ünlü ya da onun taşıyıcısı olduğu anlamlara görece daha az önem atfettiği yorumu yapılabilir.

Çalışmada ele alınan bir diğer konu olan uyum faktörünün belirleyiciliği açısından değerlendirildiğinde ise ürün-ünlü uyumu literatürüyle paralel bulgular görülmektedir (Kahle ve Homer, 1985; Kamins, 1990; Liu vd., 2007; Rice vd., 2012). Uyum düzeyine bağlı olarak hemen hemen tüm etki katsayıları sistematik bir şekilde artmış ya da azalmıştır. Buna bağı olarak tüketicinin izlediği reklama karşı tutumu ve satın alma kararında ünlüyle kurduğu ideal bağlarla birlikte ünlü ve ürüne ilişkin algıladığı uyumun belirleyici olduğunu söylemek mümkündür. Bir başka deyişle, reklama konu markaya yönelik tutumun etkisi bir yana, tüketici reklama yönelik tutum belirleyiciliğindeki satın alma kararında ünlüyle ürünün uyumunu da gözetmektedir.

Sevilirliğin iknadaki etkisi gözetildiğinde (Sharma, 1999) ise, salt fiziksel çekiciliğe atfedilen sevilmenin ötesinde kişiyi, özelde ünlüyü sevilir kılan özellikleri üzerinde odaklanmak ünlünün ikna gücünü ortaya koymak ve bundan faydalanmak anlamında önem taşır. Nitekim bu çalışmada ünlülerin fiziksel çekiciliklerine ilişkin bir önkabul olduğu düşünüldüğünde bireylerin kendilerini ünlü ile özdeşleştirmesi ve davranışsal yansımalarının görülmesi noktasında tek başına çekiciliğe bağlı değerlendirme yapmadıkları yorumunu yapmak mümkündür. Ünlünün sevilirliğine yönelik olumlu değerlendirmelerin tutum ve tutum aracılığında davranışa yansımaları göz önünde bulundurularak ünlüyü sevilir kılan özellik ya da özelliklerin ortaya konmaSı, ünlü seçiminin de bu özellikler gözetilerek yapılması gerekliliği bir diğer önemli husustur.

Bu çalışmada da ortaya konduğu üzere reklamdaki ünlü ile ürün arasındaki uyum, tutum ve davranışsal çıktıda hala belirleyici olabilirken bireyin kendi anlam dünyasının da ünlüler aracılığında reklam tutumunu etkilediği görülmektedir: Bireyin reklamda yer alan ünlü ile imrenerek kurduğu bağ reklama tepkisinde belirleyicidir. Bireyin ünlüye atfettiği anlamların bireysel sembolizminin önemli bir parçası olduğu ve reklam algısını etkilediği ortaya konmuştur. Buna dayanarak, reklamda yer alacak ünlünün seçiminde salt ünlünün hedef kitle nezdinde sevilirliği ya da popülaritesi gibi karakteristik özelliklerini gözetmekten ziyade onun hedef kitle nezdinde nasıl algılandığı ve bu algının söz konusu kitlenin ideali ve gerçekliğiyle ne ölçüde uyuştuğunun da gözetilmesi gerektiği görülmektedir. Dolayısıyla hedef pazar belirlemede artık demografik kriterlerin çok ötesine gidilirken bu çalışmada ve daha önce birçok çalışmada da ortaya konduğu üzere ürün-ünlü uyumunun ünlü seçimindeki önemiyle birlikte ünlünün hedef kitle ile uyumu da oldukça önemli bir kriter olarak karşımıza çıkmaktadır. Dolayısıyla reklamlarda ünlü kullanımına bağlı reklam etkinliğine ilişkin ampirik çalışmalar da ünlü-ürün uyumunun ötesine taşınmalıdır. Bu yorumu, bireyin sosyal kimliğinin önemli bir unsuru olan sahiplikleri, bunların seçiminde reklam, markanın rolü, bu unsurların belirleyiciliğinde de ünlü dâhil birçok taşıyıcı unsurun eklektik yapısı bağlamında da yapmak mümkündür. Bir başka deyişle sayılan her bir unsurun karşıııkı etkisi ve tutumsal ve davranışsal çıktıda ortak katkısı söz konusudur. Kısaca ifade etmek gerekirse, içinde bulunulan kültürel yapıda birçok anlamın taşıyıCISı konumundaki ünlü (Thomson, 2006) kültürel dünyanın bir temsilcisi konumundadır ve uygulamada ünlü ile tüketim ürününü bir araya getiren kreatif direktörün bu iki unsurun benzerliğinin tüketiciler tarafından doğru biçımde algılanmasına çalışmalıdır. Bunun için öncelikle üründe hangi özelliklerin arandığının açıkça belirlenmesi, sonrasında ürünün arzulanan özelliğinin kültürel dünyanın neresinde bulunacağının ortaya konması gerekir. Sonrasında ise kültürel dünyanın anlam ve değerin taşıyıcısı konumundaki reklamda (Pollay, 1983) nasıl yansıtılacağına karar verilmelidir. Bu yansıtmada ise reklamda yer alan ünlünün seçiminde reklama 
yönelik olumlu tutuma katkısı gözetilmeli; bireyin idealine ve ideal algısına en yakın konumda duran ünlü seçimi yapılmasına çalışılmalıdır. Çalışma bulgularında da görüleceği gibi ünlüye atfedilen anlamlar reklama yönelik tutumda belirleyicidir ve birey satın alma kararını markaya yönelik ve reklama tutumu referansında vermektedir. Ünlüye yönelik özenme güdüsü reklama yönelik tutumda güçlendirici rol üstlenmektedir. Tüm bu teorik tartışmaların ışığında reklamverenlere ünlü seçiminde ne sadece popülarite ne de sadece reklama konu ürün ile uyumunun tek başına gözetilmemesi gerektiği, her iki unsurun birlikte değerlendirilmesi gerektiği önerisinde bulunulabilir. Bu çalışmada da görülmüştür ki tüketici reklamda yer alan ünlü ile sosyal anlamda kendini benzer bulduğu için değil ona benzemek istediği için onun yer aldığı reklama konu ürünü satın almaktadır (Awasti ve Choraria, 2015). Bu çalışmada özenerek özdeşleşme bu eğilimi temsil etmektedir. Öte yandan tüketicinin ünlüyü, reklama konu ürün ile ilişkilendiremediği takdirde reklama yönelik tutumu ve buna bağlı olarak satın alma kararında beklenen olumlu etkinin yaratılamadığı da geçmiş birçok çalışmada ortaya konmuştur (Kamins, 1990; Rice vd., 2012; Levi vd., 2017; Jay Min vd., 2019). Tüm bunlar ışığında uygulayıcılara reklamda yer alacak ünlü seçiminde sunulacak reçete, ünlüyü tüketici nezdinde ideal kılacak olan sevilirlik, çekicilik, popülarite gibi özellikleriyle birlikte reklama konu ürünle ne ölçüde uyuştuğunun dikkate alınması olacaktır.

\section{Sınırlılıklar ve Gelecek Çalışmalara Öneriler}

Ortaya koyduğu bulgularla birlikte bu çalışma birtakım sınırlılıklar ve buna bağlı çaıışma önerileri de barındırmaktadır. Öncelikle, araştırmada ünlülerin seçimi keşifsel bir araştırmadan ziyade geçmiş araştırma bulguları referansında yapılmıştır. Bunun için ünlü seçimi de ön araştırma yapılarak farklı bir zenginlik katılabilir. Çalışmada katılımcılara sadece reklam videoları izlettirilmiş olup alternatif çalışmalar farklı mecralarda sunulan reklam içerikleriyle tekrarlayabilirler.

Bu araştırmada ürün grubuna ilişkin farklılaşmadan bağımsız uyum düzeyleri gözetilmiştir. Araştırma, ürün grupları çeşitlendirilerek bunlara bağı ayrışma olup olmadığı şeklinde yeniden tasarlanabilir. Yine dört uyum düzeyiyle sınırlandırılan bu araştırma uyum düzeyleri çeşitlendirilmek suretiyle uyumun belirleyiciliğine ilişkin daha net bir resim sunulabilir.

Söz konusu bu araştırma ünlü-tüketici uyumunu arzu edilen ve algılanan boyutuyla özenme ve benzeşme olarak ele almıştır. Söz konusu özdeşleşme yapısı itibariyle erkek ve kadın katılımcıların maruz kaldıkları reklamlar hemcinsleri ünlülerin yer aldığı içeriklere sahiptir. Daha önce Choi ve Rifon'un (2012) doğrudan benlik algılarını incelediği çalışma bu çalışmada özdeşleşme boyutu itibariyle ele alınmıştır. Alternatif bir yapı ile her cinsiyette katılımcının iki cinsiyette ünlüye maruz kaldığı yeni tasarımlar yapılabilir ve ünlünün cinsiyetinin bireyin cinsiyetiyle etkileşimi incelenebilir.

Bu çalışmada ünlü seçimi spor ve şarkıcı olmak üzere iki alandan yapılmıştır. Alternatif çalışmalar farklı uzmanlık alanlarından ünlü seçimi yapabileceği gibi ulusal ve bazen uluslararası bilinirlikte ünlülerle birlikte günümüz iletişim teknolojilerinin sağladığı imkânlarla sayıları hızla artan, mikro-ünlüler (micro-celebrity) ya da yerel ünlü (local celebrity) olarak kavramsallaştırılan (Ferris, 2010; Marwick ve Boyd, 2011) yeni dönem ünlülerinin yer aldığı reklam tasarımlarıyla karşılaştırmalı olarak yeniden tasarlanabilir. 


\section{Eskişehir Osmangazi Üniversitesi IïB Dergisi}

\section{Kaynaklar}

Awasthi, Ashwini K. \& Choraria, Sapna. (2015), "Effectiveness of Celebrity Endorsement Advertisements: The Role of Customer Imitation Behaviour", Journal of Creative Communications, Vol. 10, No.2: 215-234.

Baker, Michael J. \& Churchhill, Gilbert A. (1977), "The Impact of Physically Attractive Models on Advertising Evaluations", Journal of Marketing Research, Vol.14, No.4: 538-555.

Bandura, Albert (1977), "Self-efficacy: Toward a Unifying Theory of Behavioral Change", Psychological Review, Vol. 84, No.2: 191-215.

Bandura, Albert (2001), "Social cognitive theory of mass communication”, Media Psychology, V.3: 265-299.

Basil, Michael (1996), "Identification as a Mediator of Celebrity Effects", Journal of Broadcasting and Electronic Media, Vol. 40, No.4: 478-495.

Batra, Rajeev \& Homer, Pamela Miles (2004), "The Situational Impact of Brand Image Beliefs", Journal of Consumer Psychology, V. 14, I. 3: 318-30.

Belk, Russell W. (1988), "Possessions and the Extended Self”, Journal of Consumer Research, Vol. 15, No. 2: $139-68$.

Bergkvist, Lars \& Zhou, Kris Qiang. (2016), "Celebrity Endorsements: A Literature Review And Research Agenda", International Journal of Advertising, Vol. 35, No. 4: 642-663.

Bergkvist, Lars, Hjalmarson, Hanna \& Mägi, Anne W. (2016), “A New Model of How Celebrity Endorsements Work: Attitude Toward the Endorsement as A Mediator of Celebrity Source and Endorsement Effects", International Journal of Advertising, Vol. 35, No. 2: 171-184.

Biswas, Somdutta, Hussain, Mahmood \& O’Donnell, Kathleen (2009), “Celebrity Endorsements in Advertisement and Consumer Perceptions: A Cross-Cultural Study", Journal of Global Marketing, Vol. 22, No. 2: 121-137.

Boon, Susan Diaanne \& Lomore, Christine D. (2001), “Admirer-Celebrity Relationships Among Young Adults: Explaining Perceptions of Celebrity Influence on Identity", Human Communication Research, Vol. 27, No. 3: $432-465$.

Braunstein, Jessica R. \& Zhang, James J. (2005), "Dimensions of Athletic Star Power Associated With Generation Y Sports Consumption", International Journal of Sports Marketing and Sponsorship, July: 37-62.

Boyd, Thomas C. \& Shank, Matthew D. (2004), "Athletes as Product Endorsers: The Effect of Gender and Product Relatedness", Sport Marketing Quarterly, Vol. 13, No. 2: 82-93.

Brown, William J. \& Basil, Michael (1995), “Media Celebrities and Public Health: Responses to 'Magic' Johnson's HIV Disclosure and Its Impact on AIDS Risk and High-Risk Behaviors", Health Communication, Vol. 7, No. 4: 45-70.

Byrne, Donn Erwin (1971), The Attraction Paradigm, New York: Academic Press.

Caldwell, Marylouise \& Henry, Paul (2005), "Celebrity Worship, Micro-Communities and Consumer Well-Being", 8th International Conference on Arts and Cultural Management, Montreal, Canada, 6th July 2005

Caughey, John L. (1985), “Mind Games: Imaginary Social Relationships in American Sport”, (Ed. G.A. Fine), Meaningful play, Playful Meaning, Champaign, IL: Human Kinetics Publishers: 19-33.

Chan, Kara \& Prendergast, Gerard (2008), "Social Comparison, Imitation of Celebrity Models and Materialism Among Chinese Youth", International Journal of Advertising, Vol. 27, No. 5: 799-826.

Choi, Sejung Marina \& Rifon, Nora J. (2012), "It Is a Match: The Impact of Congruence Between Celebrity Image and Consumer Ideal Self on Endorsement Effectiveness", Psychology and Marketing Vol. 29, No. 9: 639-650.

Chory-Assad, Rebecca M \& Yanen, Ashley (2005), “Hopelessness and Loneliness as Predictors Of Older Adults' Involvement With Favorite Television Performers", Journal of Broadcasting \& Electronic Media, Vol. 49, No. 2: 182201.

Daneshvary, Rennae \& Schwer, R. Keith (2000), "The Association Endorsement and Consumers' Intention to Purchase", Journal of Consumer Marketing, Vol. 17: 203-213

Eisend, Martin \& Langner, Tobias (2010), “Immediate and Delayed Advertising Effects of Celebrity Endorsers' Attractiveness and Expertise", International Journal of Advertising, Vol. 29, No. 4: 527-546.

Erdogan, B. Zafer (1999), "Celebrity endorsement: A literature review”, Journal of Marketing Management, Vol.15: 291- 314 .

Escalas, Jennifer Edson \& Bettman, James R. (2003), "You Are What They Eat: The Influence of Reference Groups on Consumers' Connections To Brands", Journal of Consumer Psychology, Vol. 13: 339-348.

Eyal, Keren \& Rubin, Alan M. (2003), "Viewer Aggression and Homophily, Identification, and Parasocial Relationships With Television Characters", Journal of Broadcasting \& Electronic Media, Vol. 47, No. 1: 77-98. 
Fornell, Claes \& Larcker, David F. (1981), "Evaluating Structural Equation Models With Unobservable Variables and Measurement Error", Journal of Marketing Research, Vol. 18, No. 1: 39-50.

Fraser, Benson P. \& Brown, William J. (2002), "Media, Celebrities, and Social Influence: Identification With Elvis Presley", Mass Communication and Society, Vol. 5, No. 2: 183-206.

Friedman, Hershey H. \& Friedman, Linda (1979), "Endorser Effectiveness by Product Type”, Journal of Advertising Research, 19 (October/November): 63-71.

Giles, David (2000), Illusions of Immortality: A Psychology of Fame and Celebrity, Basingstoke: Macmillan.

Green, A.L. \& Adams-Price, Carolyn (1990), “Adolescents' Secondary Attachments to Celebrity Figures”, Sex Roles, Vol. 23, No. 7/8: 335-347.

Grubb, Edward L. \& Grathwohl, Harrison L. (1967), “Consumer Self-Concept Symbolism and Market Behavior: A Theoretical Approach", Journal of Marketing, Vol. 31, No. (4, PT.1): 22-27.

Halonen-Knight, Elina \& Hurmerinta Leila (2010), "Who Endorses Whom? Meanings Transfer in Celebrity Endorsement", Journal of Product \& Brand Management, Vol. 19, No. 6: 452-460.

Harwood, Jake (1999), "Age Identification, Social Identity Gratifications, and Television Viewing”, Journal of Broadcasting \& Electronic Media, Vol. 43, No.1: 123-136.

Heider, Fritz (1958), "The Psychology of Interpersonal Relations, New York: Wiley.

Higgins, E. Tory (1987), "Self-Discrepancy: A Theory Relating Self and Affect”, Psychological Review, Vol. 94: 319-340.

Hirschman, Elizabeth C. (1981), Comprehending Symbolic Consumption: Three Theoretical Issues. In Elizabeth C. Hirschman and Morris B. Holbrook (Eds.) SV - Symbolic Consumer Behavior. New York, NY: Association for Consumer Research, Pages: 4-6.

Hoffner, Cynthia (1996), “Children's Wishful Identification and Parasocial Interaction With Favorite Television Characters", Journal of Broadcasting and Electronic Media, Vol. 40, No. 3: 389-402.

Hoffner, Cynthia \& Buchanan, Martha (2005), "Young Adults' Wishful Identification With Television Characters: The Role of Perceived Similarity and Character Attributes", Media Psychology, Vol. 7, No. 4: 325-351.

Hofstede, Geert (2001), Culture's Consequences: Comparing Values, Behaviors, Institutions, and Organizations Across Nations, Thousand Oaks, California: Sage.

Hovland, Carl I. \& Weiss, Walter (1951), "The Influence of Source Credibility on Communication Effectiveness", Public Opinion Quarterly, Vol. 15, No. 4: 635-650.

$\mathrm{Hu}$, Li-tze \& Bentler, Peter M. (1999), "Cutoff Crirteria For Fit Indexes in Covariance Structure Analysis. Conventional Criteria Versus New Alternatives", Structural Equation Modelling, Vol. 6, No. 1:1-55.

Min, Jae Han Jay, Chang, Hyo Jung Julie, Jai, Tun-Min Catherine \& Ziegler, Morgan (2019), "The effects of celebritybrand congruence and publicity on consumer attitudes and buying behavior", Fashion and Textiles, Vol. 6, No.10: 1-19.

Jin, Seung-A Annie \& Phua, Joe (2014), “Following Celebrities' Tweets About Brands: The impact of Twitter-Based Electronic Word-Of-Mouth on Consumers' Source Credibility Perception, Buying Intention, and Social Identification With Celebrities", Journal of Advertising, Vol. 43, No. 2: 181-195.

Johar, J. S. \& Sirgy, M. Joseph (1991), "Value-Expressive Versus Utilitarian Advertising Appeals: When and Why to Use Which Appeal", Journal of Advertising, Vol. 20, No. 3: 23-33

Kahle, Lynn R. \& Homer, Pamela M. (1985), "Physical Attractiveness of The Celebrity Endorser: A Social Adaptation Perspective", Journal of Consumer Research, Vol. 11, No. 4: 954-961.

Kamins, Michael A. (1990), "An Investigation Into The "Match-up" Hypothesis in Celebrity Advertising: When Beauty May Be Only Skin Deep", Journal of Advertising, Vol. 19, No. 1: 4-13.

Kapitan, Sommer \& Silvera, David H. (2016), "From Digital Media Influencers to Celebrity Endorsers: Attributions Drive Endorser Effectiveness", Marketing Letters, Vol. 27, No. 3: 553-567.

Keel, Astrid \& Nataraajan, Rajan (2012), "Celebrity Endorsements and Beyond: New Avenues For Celebrity Branding", Pscyhology and Marketing, Vol. 29, No. 9: 690-703.

Kelley, Harold H. (1973), "The Process of Causal Attribution”, American Psychologist, Vol. 28, No. 2: $107-128$.

Kelman Herbert C.(1961), “Processes of Opinion Change”, Public Opinion Quarterly, Vol. 25: 57-78. 


\section{Eskişehir Osmangazi Üniversitesi Iïß Dergisi}

Lafferty, Barbara A. \& Goldsmith, Ronald E. (1999), “Corporate Credibility's Role In Consumers' Attitudes and Purchase Intentions When A High Versus A Low Credibility Endorser Is Used in The Ad", Journal of Business Research, Vol. 44, No. 2: 109-116.

Levi, Eser, Varnalı, Kaan \& Babür Tosun, Nurhan (2017), "The Match-Up Hypothesis Revisited: A Social Psychological Perspective", International Journal of Communication, Vol. 11, No. 2017: 278-300

Levy, Sidney J. (1959), "Symbols for Sale”, Journal of Consumer Research, Vol. 10, No. September: 169-180.

Liu, Matthew Tingchi \& Brock, James L. (2011), "Selecting A Female Athlete Endorser in China: The Effect of Attractiveness, Match-Up, and Consumer Gender Difference", European Journal of Marketing, Vol. 45, No. 7/8: 12141235.

MacKenzie, Scott B., Lutz, Richard J. \& Belch, George E. (1986), "The Role of Attitude Toward The Ad As A Mediator of Advertising Effectiveness: A Test of Competing Explanations", Journal of Marketing Research, Vol. 23, No. 2: 130143.

Marsh, Herbert W. \& Hocevar, Dennis (1985), "Application of Confirmatory Factor Analysis to The Study of SelfConcept: First and Higher Order Factor Models and Their Invariance Across Groups", Psychological Bulletin, Vol. 97, No. 3: 562-582.

Martin, Craig A. \& Bush, Alan J. (2000), “Do Role Models Influence Teenagers' Purchase Intentions and Behavior?", Journal of Consumer Marketing, Vol. 17, No. 5: 441-453.

Marwick, Alice \& Boyd, Danah (2011), "To See and Be Seen: Celebrity Practice on Twitter", Convergence: The International Journal of Research into New Media Technologies, Vol. 17, No. 2: 139-158.

McCracken, Grant (1989), "Who is The Celebrity Endorser? Cultural Foundations of The Endorsement Process", Journal of Consumer Research, Vol. 16, No. 3: 310-321.

McGuire, William J. (1985), Attitudes And Attitude Change. In G. Lindzey and E. Aronson (Eds.), Handbook of social psychology (3rd ed.), Volume II: Special fields and applications. New York: Random House.

Miniard, Paul W., Bhatla, Sunil \& Rose, Randall L. (1990), “On The Formation And Relationship Of Ad And Brand Attitudes: An Experimental And Causal Analysis", Journal of Marketing Research, Vol. 27, No. 3: 290-303.

Nam-Hyun Um, (2013), "Effects Of Negative Brand Information: Measuring Impact Of Celebrity Identification And Brand Commitment", Journal of Global Marketing, Vol. 26, No. 2: 68-79.

Obot, Isidore S. (1988), "Value Systems And Cross-Cultural Contact: The Effect Of Perceived Similarity And Stability Of Social Evaluations", International Journal of Intercultural Relations, Vol. 12, No. 4: 363-379.

Ogden, Harold J. \& Venkat, Ramesh (2001), "Social Comparison And Possessions: Japan Vs Canada", Asia Pacific Journal of Marketing and Logistics, Vol. 13, No. 2: 72-84.

Ohanian, Roobina (1990), “Construction And Validation Of A Scale To Measure Celebrity Endorsers' Perceived Expertise, Trustworthiness, And Attractiveness", Journal of Advertising, Vol. 19, No. 3: 39-52.

Ohanian, Roobina (1991), "The Impact of Celebrity Spokesperson's Perceived Image On Consumers' Intention To Purchase", Journal of Advertising Research, Vol. 31, No. 1: 36-52.

Oliver, Richard L. \& Bearden, William O. (1985), "Crossover Effects in The Theory Of Reasoned Action: A Moderating Influence Attempt", Journal of Consumer Research, Vol. 12, No. 3: 324-340.

Park, C. Whan \& Lessig, V. Parker (1977), "Students And Housewives: Differences in Susceptibility To Reference Group Influence", Journal of Consumer Research, Vol. 4, No.2: 102-110.

Peetz, Ted B.; Parks, Janet B. \& Spencer, Nancy E. (2004), "Sport Heroes As Sport Product Endorsers: The Role Of Gender in The Transfer Of Meaning Process For Selected Undergraduate Students", Sport Marketing Quarterly, Vol. 13, No. 3: 141-150.

Perloff, Richard M. (2003), The Dynamics Of Persuasion. Communication And Attitudes in The 21st Century (2nd ed), New Jersey: Lawrence Erlbaum.

Petty, Richard E. \& Cacioppo, John T. (1996), Attitudes And Persuasion: Classic And Contemporary Approaches, USA: Westview Press.

Pollay, Richard W. (1983), "Measuring the Cultural Values Manifest in Advertising", Current Issues and Research in Advertising, Vol. 6, No. 1: 71-92.

Rashotte, Lisa. (2007), "Social Influence", (Ed. G. Ritzer), The Blackwell Encyclopedia of Sociology, Blackwell Publishing: 4426-4429. 
Ratneshwar, S. \& Chaiken, Shelly (1991), “Comprehension's Role in Persuasion: The Case Of Its Moderating Effect On The Persuasive Impact Of Source Cues", Journal of Consumer Research, Vol. 18, No. 1: 52-62.

Rice, Dan Hamilton; Kelting, Katie \& Lutz, Richard J. (2012), “Multiple Endorsers And Multiple Endorsements: The Influence Of Message Repetition, Source Congruence And Involvement On Brand Attitudes", Journal of Consumer Psychology, Vol. 22, No. 2: 249-259.

Roy, Subhadip; Gammoh, Bashar \& Koh, Anthony C. (2012), "Predicting The Effectiveness Of Celebrity Endorsements Using The Balance Theory", Journal Of Customer Behaviour, Vol. 11, No. 1: 33-52.

Sarıkaya, Nilgün \& Barutçu, Merve Türkmen (2016), "11-14 Yaş Arası Illk Dönem Çocuk Ergen Tüketicilerin Alışveriş Davranışlarında Ünlü Kişi Etkisi”, Pazarlama ve Pazarlama Araştırmaları Dergisi, Cilt: 17, Sayı: 1: 43-64.

Schaefer, Allen \& Keillor, Bruce (1997), "The Effective Use Of Endorsements in Advertising: The Relationship Between "Match-Up" And Involvement", The Journal of Marketing Management, Vol. 7, No. 2: 23-33.

Sharma, Arun (1999), "Does The Salesperson Like The Customers? A Conceptual And Empirical Examination Of The Persuasive Effect Of Perceptions Of The Salesperson's Affect Toward Customers", Psychology and Marketing, Vol. 16, No. 2: 141-162.

Simmers, Christina S.; Damron-Martinez, Datha \& Haytko, Diana L. (2009), "Examining The Effectiveness Of Athlete Celebrity Endorser Characteristics And Product Brand Type: The Endorser Sexpertise Continuum", Journal of Sport Administration \& Supervision, Vol. 1, No. 1: 52-64.

Simpson, Eithel M., Snuggs, Thelma, Christiansen, Tim \& Simples, Kelli E. (2000), "Race, Homophily, And Purchase Intentions And The Black Consumer", Psychology and Marketing, Vol. 17, No. 10: 877-889.

Sirgy, M. Joseph (1998), "Materialism And Quality Of Life”, Social Indicators Research, Vol. 43, No. 3: 227-260.

Tabachnick, Barbara G. \& Fidell, Linda S. (2001), Using Multivariate Statistics (4th ed.). MA: Allyn \& Bacon, Inc.

Tan, D.T. Yeong \& Singh, Ramadhar (1995), “Attitudes And Attraction: A Developmental Study Of The SimilarityAttraction And Dissimilarity-Repulsion Hypotheses", Personality and Social Psychology Bulletin, Vol. 21, No. 9: 975-986.

Taylor, Charles R. (2016), "Some Interesting Findings About Super Bowl Advertising", International Journal of Advertising, Vol. 35, No. 2: 167-170.

Thomson, Matthew (2006), “Human Brands: Investigating Antecedents To Consumers' Strong Attachments To Celebrities", Journal of Marketing, Vol. 70, No. 3:104-119.

Till, Brian D. \& Busler, Michael (2000), "The Match-Up Hypothesis: Physical Attractiveness, Expertise, And The Role Of Fit On Brand Attitude, Purchase Intent And Brand Beliefs", Journal of Advertising, Vol. 29, No .3: 1-13.

v. Feilitzen, Cecilia \& Linné, Otto (1975), "The Effects Of Television On Children And Adolescent", Journal of Communication, Vol. 25, No. 4, 51-55.

Wang, Stephen W. \& Scheinbaum, Angeline Close (2018), “Enhancing Brand Credibility Via Celebrity Endorsement Trustworthiness Trumps Attractiveness And Expertise", Journal of Advertising Research, Vol. 58, No. 1: 16-32.

Woodruff-Burton, Helen \& Elliott, Richard (2005), Compensatory Consumption and Narrative Identity Theory. In Geeta Menon and Akshay R. Rao (Eds) NA -Advances in Consumer Research, Volume 32. Duluth, MN: Association for Consumer Research, Pages: 461-465.

Wright, Scott A. (2016), "Reinvestigating The Endorser By Product Matchup Hypothesis in Advertising", Journal of Advertising, Vol. 45, No. 1: 26-32. 


\section{Extended Summary}

\section{The moderating role of celebrtiy-product match-up on the effectof identification on attitude towards advertising and purchase intention}

Since consumption has an important role in the provision of meaning and values for the creation and maintenance of the individual's personal and social world, advertising is seen as one of the main sources of these symbolic meanings. The symbolic sources that the individual can use in self-formation can be classified as direct or indirect experiences. Direct experience covers everyday life practices and experiences gained through face-to-face encounters. Indirect experiences include the consumption of mass communication culture and media products and differ from everyday life practices. The use of celebrities in advertising in the context of media consumption is also one of the advertising strategies frequently applied. According to McCracken (1989), celebrity is the person who is known by the society and uses this awareness in the advertisement by using it in the name of that product / brand. Through celebrity endorsement, the celebrity becomes a part of a product and therefore meaning by recommending a product, giving its name to a product, being an advertising face or becoming a brand ambassador. Many studies have been carried out in the field, the majority of which are about the characteristics of the celebrity in the source position and the congruence between the celebrity and the advertised product. Depending on the source characteristics, the persuasion effect on the target audience has been the subject of many studies and has been associated with Kelman's Social Influence Theory (1961). The three processes that Kelman put forward as Social Influence Theory are the processes of compliance, identification and internalization, and identification and internalization are two processes that are used in the use of celebrities in advertisements. Accordingly, it is expected that the audience will tend to identify with the the celebrity to the extent that $\mathrm{s} / \mathrm{he}$ finds him/her attractive, and internalize the message the celebrity gives to the extent $\mathrm{s} /$ he finds him/her reliable. As stated by Kapitan and Silvera (2016), identification with the celebrity is rarely studied and this study handled this topic and the strength of the identification bond established with the celebrity depending on gender was tested. With this research, the sampling frame has been moved beyond the children and identified as individuals who can be exposed to advertising content over the age of 18 and over by various mass media (Television or online content). Although there are many studies on celebrity-product match-up, the vast majority of them are based on hypothetical ad designs. This study is important in terms of being designed with real celebrities and real ads-brands with them, but also included the identification that is interpreted as consumer-celebrity congruence in the use of celebrities in advertisements. Another unique contribution of the study is the simultaneous examination of congruence both as consumer-celebrity and product-celebrity, and interpretation of their interaction during advertising effectiveness. As of the literature searched, there is no study examining the subject in this context and this design.

In this study, a male athlete (Arda Turan) and a female singer celebrity (Hadise) and the advertisements they feature(d) searched. Following the preliminary research, the level of match-up between celebrities and the products / brands in their advertisement was revealed. With the pilot study, this rating regarding the level of congruence was checked and the clarity of the scale expressions in the data collection tool was tested by the second stage preliminary research. Finally, a model test was carried out with the main research conducted. Identification construct, which is the carrier of the original quality of the study, was examined under two dimensions depending on admiration based wishful identification and perception of similarity based similarity identification. Predicted hypotheses:

$\mathrm{H} 1$ : Identification of the individual with the celebrity in the advertisement (wishful and similarity);

$\mathrm{H} 1 \mathrm{a}$ : positively affects the attitude towards the advertisement.

$\mathrm{H} 1 \mathrm{~b}$ : positively affects the intention to purchase the brand in the advertisement

$\mathrm{H} 2$ : Attitude towards advertising has a positive effect on purchase intent.

H3: Celebrity-product match-up in advertising

$\mathrm{H} 3 \mathrm{a}$ : has a moderator role strengthening the effect of identification on the attitude towards advertising.

$\mathrm{H} 3 \mathrm{~b}$ : has a moderator role strengthening the effect of identification on purchase intent

$\mathrm{H} 3 \mathrm{c}$ : has a moderator role that strengthens the effect of the attitude towards advertising on the purchase intent.

Research findings show that identification does not have a direct effect on purchase intent, while wishful identification has an indirect effect through attitudes towards advertising. Similarity identification has neither direct nor indirect effects on purchase intent. In the second stage data analysis, it has been examined whether there is a change 
in the coefficients according to the celebrity-product / brand match-up. The findings obtained at this stage are that the coefficients of effects increase systematically as the perceived match-up between celebrity and product / brand increases.

In this study, where the match-up between celebrities and consumers and their contribution to advertising effectiveness was tested, it has been revealed that the admiration-based ties established with the celebrity contributed to the advertising evaluation and purchase intent. In the current study, it has also been revealed that while the individual has a more positive attitude towards the ads the celebrity appears in, s/he will also show a tendency to purchase the brand in the advertisement through the attitude towards advertising. Match-up related findings are also compatible with previous research findings. It is possible to say that the consumer's attitude towards advertisement is affected by the ideal ties $s /$ he establishes with the celebrity and the match-up $s /$ he perceives regarding the product and the celebrity. In other words, aside from the effect of the attitude towards the brand, the consumer also considers the match-up between the product and these all affect their purchase decision as well. As revealed in this study, while the match-up between the celebrity and the product in advertising is an important determinant in the attitudinal and behavioral output, the individual's own world of meaning also affects the advertising attitude through the celebrities. Individual's admiration feeling is decisive in their reaction to the advertisement. It has been revealed that the meanings the individual attributes to celebrity are important parts of individual symbolism and affect the perception of advertising. Based on this, it is seen that the selection of the celebrity who will be included in the advertisement would not only be based on his/her features such as popularity or likeability but also be based on how the celebrity is perceived among the target audience and to what extent this perception matches the ideal self and reality of the audience. Advertisers can be advised that the match-up between the celebrity and the product should not be taken into consideration alone, nor should both match-up between the celebrity and the product and celebrity popularity be evaluated together. It was also seen in this study that the consumer buys the product / brand in the advertisement not because $s /$ he finds himself/herself similar with the celebrity in social sense but s/he wants to be like him/her with a feeling of admration. Wishful identification in this study represents this intention. On the other hand, if the consumer cannot associate the celebrity with the product in the advertisement, the attitude towards the advertisement and the expected positive effect in the purchase decision could not be created as revealed in many previous studies. In the light of all this, the recipe to be presented to the practitioners in the selection of the celebrity to be included in the advertisement would be that they would rather take into consideration to what extent the celebrity fits with the product in the advertisement together with his/her features such as likeability, attractiveness and popularity. 
Eskişehir Osmangazi Üniversitesi IïBF Dergisi 